\title{
HbE- THALASSEMIA: A CASE REPORT
}

\author{
Keriyatt Govindan Sajeethkumar ${ }^{1}$, Aquil Kalanad², Vadakke Puthanveettil Thushar ${ }^{3}$, Anoop Naduvilpattu ${ }^{4}$
}

${ }_{1}^{1}$ Additional Professor, Department of General Medicine, Government Medical College, Calicut. 2 Assistant Professor, Department of General Medicine, Government Medical College, Calicut. ${ }^{3}$ Senior Resident, Department of General Medicine, Government Medical College, Calicut. 4Junior Resident, Department of General Medicine, Government Medical College, Calicut.

\section{ABSTRACT}

\section{BACKGROUND}

$\mathrm{HbE}$ is a variant haemoglobin with a mutation in beta-globin gene, which is the most common Hb variant in South-East Asia. Here, we present a case report of 17 yrs. old boy presented with symptoms of anaemia and unusual head shape. HbE alone is clinically silent and it manifests when it mingles with Thalassemia.

\section{KEYWORDS}

HbE, Beta Globin, Erythropoiesis, Haemoglobinopathy, Thalassemia, Haemolysis.

HOW TO CITE THIS ARTICLE: Sajeethkumar KG, Kalanad A, Thushar VP, et al. HbE- thalassemia: a case report. J. Evolution Med. Dent. Sci. 2016;5(36):2169-2170, DOI: 10.14260/jemds/2016/505

\section{INTRODUCTION}

A 17 yrs. old boy studying in 9th Std. coming from West Bengal. He presented with complaints of Fatigue for 8 yrs., unusual size of head for 6 yrs. Yellowish discolouration of eyes for 8-9 months and abdominal discomfort and exertional dyspnoea for 8 months. His complaints started as mild fatigue 8 yrs. back and the parents noticed increased size of head 6 yrs. back. But these complaints were neglected. For the last 89 months he is having jaundice, abdominal discomfort and exertional dyspnoea which made him to consult a doctor. No h/o recurrent infections or bleeding manifestations. No h/o blood transfusions. No h/o recurrent leg ulcers. No h/o loss of weight or appetite. He has 2 brothers and 3 sisters, of which 1 brother has h/o similar illness but not severe and not taking any treatment. No h/o surgeries in the family.

On general examination he was conscious and oriented, Severe pallor (+), Mild icterus (+). No clubbing, cyanosis, lymphadenopathy or pedal oedema. PR-84/min, regular. BP$110 / 70 \mathrm{mmHg}$. He was afebrile at the time of examination. Frontal bossing (+), Flat nasal bridge (+). On system examination: P/A- Liver palpable $3 \mathrm{~cm}$ below RCM with a Liver span- $15 \mathrm{~cm}$, Massive splenomegaly (+) crossing the level of umbilicus. Other system examination was within normal limits.

Investigations showed: TC-5600, DC- N76 L12, Hb-5.6 HCT-16.4, MCV-68, MCH-20.9, MCHC-30, RDW- 30.5, PLT4.8L, ESR -19, URE: Alb- nil, Sug- nil, UBG- $(+++)$, RFT 24/0.8, RBS-88, Na/K-136/4.1, TB/DB-7.3/1.0, TP/Alb8.6/5.1, ALT-25, AST- 32, ALP-122. Reticulocyte count- 5.8\%, S. Ferritin-315 (23-322), Osmotic fragility test-negative. P. Smear showed Microcytic hypochromic anaemia, Microspherocytes and fragmented RBCs with evidence of haemolysis.

Financial or Other, Competing Interest: None

Submission 19-03-2016, Peer Review 14-04-2016,

Acceptance 20-04-2016, Published 05-05-2016.

Corresponding Author:

Dr. Anoop Naduvilpattu,

Punchath Nandhanam House,

Marathamkode Post,

Kidangoor,

Thrissur-680604

E-mail:nanoop1988@gmail.com

DOI: $10.14260 /$ jemds $/ 2016 / 505$
WBC and Platelets normal. USG abdomen revealed borderline hepatomegaly and massive splenomegaly. HPLC showed $\mathrm{Hb}$ A2- $67 \%$ and $\mathrm{Hb} \mathrm{F}-29 \%$ and these findings are suggestive of $\mathrm{HbE}$-Homozygous state. But $\mathrm{HbE}$ alone will not produce this much severe clinical presentation. So we proceeded with $\mathrm{Hb}$ electrophoresis and which showed $\mathrm{Hb}$ fractions $\mathrm{Hb}$ A-6.7\%, Hb F- 34.2\%, Hb E- 53.2\%, Hb A2- 5.9\% and these findings were suggestive of compound heterozygosity for HbE/Beta Thalassemia.

So we kept the final diagnosis as congenital haemolytic anaemia- $\mathrm{HbE} /$ Beta Thalassemia Heterozygous state. Treated with packed cell transfusions to raise the $\mathrm{Hb}$.

\section{DISCUSSION}

Haemoglobin ( $\mathrm{Hb}) \mathrm{E}$ is one of the world's most common and important mutations.[1] It has replaced $\beta$-thalassemia as the most common Haemoglobinopathy in many countries. The World Health Organization (WHO) estimates that in Thailand at least 100,000 new cases of $\mathrm{Hb} \mathrm{E} \beta$-thalassemia are expected in the next few decades.[1,2] High estimates are predicted for India, Sri Lanka, Malaysia and Southern China The phenotype for patients with similar mutations can range from asymptomatic to transfusion dependent.[2]

$\mathrm{Hb} \mathrm{E}$ is formed by a substitution of glutamic acid by lysine at codon 26 of the $\beta$-globin gene as a result of a splice site mutation on exon 1 of the beta-globin gene. This mutation also activates a cryptic mRNA splice site, which results in reduced synthesis of the $\beta$-E chain and leads to a thalassemia phenotype. $\mathrm{Hb} \mathrm{E}$ has a weakened $\alpha / \beta$ interface, leading to some instability during conditions of increased oxidant stress. Hb E trait has no clinical significance. Patients may have mild microcytosis without anaemia.[3] The red cell morphology may show targeting and may be similar to other thalassemia traits or mild thalassemia intermedia conditions. ${ }^{[4]}$

It is known to be unstable at high temperatures. The crystal structures of $\mathrm{HbA} 2$ and $\mathrm{HbE}$ have been established at 2.20 and 1.74 angstroms resolution, respectively. This is the reason why $\mathrm{HbE}$ is filtered along with $\mathrm{HbA} 2$ in HPLC. So to differentiate between these two ( $\mathrm{HbE}$ and $\mathrm{HbA2}$ ), we need $\mathrm{Hb}$ electrophoresis. $\mathrm{Hb} \mathrm{E} \beta+-$ thalassemia may have an extremely variable laboratory picture. They usually have a mild anaemia of approximately $9.5 \mathrm{~g} / \mathrm{dL}$. However, significant ranges of 
anaemia has been observed with $\mathrm{Hb}$ as low as $5.7 \mathrm{~g} / \mathrm{dL}$. The Mean Corpuscular Volume (MCV) has been approximately $72 \pm 6 \mathrm{fL}$ and mean corpuscular $\mathrm{Hb}$ concentration (MCHC) has been $29 \pm 2 \mathrm{fL}$. The electrophoresis demonstrates both $\mathrm{Hb} \mathrm{E}$ and $\mathrm{Hb} \mathrm{A}$ with a marked range for the amount of $\mathrm{Hb} \mathrm{A}$. In neonates, DNA analysis is required to differentiate these two syndromes in neonates and is increasingly being used routinely for diagnosis of $\mathrm{Hb} \mathrm{E}$ disorders. ${ }^{[5]}$

\section{HbE Disease Presents in 3 Forms Namely}

- Heterozygous State (Genotype AE or HbE trait).

- Homozygous State (Genotype EE or Hb E disease).

- Compound Heterozygous states.

- Hb E Beta Thalassemia (E Thalassemia).

- Sickle Cell/HbE Disease (SE Genotype).

The most serious $\mathrm{Hb} \mathrm{E}$ syndrome is $\mathrm{Hb} \mathrm{E} \beta 0$ thalassemia. The compound heterozygote state of $\mathrm{Hb} \mathrm{E} \beta$ thalassemia results in a variable phenotype ranging from a complete lack of symptoms to transfusion dependency. Approximately, one-half of the patients are phenotypically similar to patients with thalassemia major who require regular transfusion therapy and the other half resembles thalassemia intermedia.[1,3] The pathophysiology of $\mathrm{Hb}$ E $\beta$ thalassemia is complex. Ineffective erythropoiesis, apoptosis, and oxidative damage are central components of the disease and its shortened red cell survival. The interaction between $\mathrm{Hb} \mathrm{E}$ and $\beta$-thalassemia alleles is the main determinant in the pathophysiology.[1] $\mathrm{Hb} F$ level is the strongest predictor of morbidity. However, the basis of increased $\mathrm{Hb} \mathrm{F}$ is usually unknown.[4,6] The degree of severity is also affected by the type of $\beta$-thalassemia mutation. Co-inheritance of $\alpha$ thalassemia mutations decrease the globin chain imbalance and improve the anaemia. This occurs in fewer than $15 \%$ of patients. Triplicated or quadruplicated $\alpha$-globin genes increase the severity of E-thalassemia and occur in approximately $4 \%$ of the population. ${ }^{7,8]}$

The clinical course of $\mathrm{E} \beta$-thalassemia is punctuated by acute and chronic complications that may cause serious morbidity and mortality. The marked expansion of erythropoiesis is responsible for much of the pathology of the disease including hepatosplenomegaly, extramedullary haematopoietic masses, growth retardation, delayed sexual maturation and bone deformities.[1,3] Splenomegaly often develops in severely affected patients. Iron overload in nontransfused patients is common secondary to increased gastrointestinal absorption of iron. End-organ failure secondary to iron overload may not be suspected because the serum ferritin level is disproportionately low. ${ }^{[9]}$
Cardiopulmonary disease is the most common cause of death in $\mathrm{Hb} \mathrm{E} \beta$-thalassemia. Patients with $\mathrm{Hb} \mathrm{E} \beta$-thalassemia are excellent candidates for agents directed at elevating $\mathrm{Hb} F$ production. A small increase in the steady-state haemoglobin concentration might be of major clinical benefit.[9,10]

\section{CONCLUSION}

$\mathrm{HbE}$ is a common abnormal $\mathrm{Hb}$ variant, which is an unstable form. Homozygous condition usually asymptomatic and almost silent and it becomes manifested when it mingles with Thalassemia. So high degree of suspicion and evaluation is needed, especially when the patient is coming from a prevalent area.

\section{REFERENCES}

1. Gibbons R, Higgs DR, Olivieri NF, et al. The $\beta$ and $\delta \beta$ thalassaemias in association with structural haemoglobin variants. In: Weatherall DJ, Clegg JB, eds. The thalassaemia syndromes. Oxford, United Kingdom: Blackwell Science 2001; $4^{\text {th }}$ edn:393-449.

2. Lorey F. Asian immigration and public health in California: thalassemia in newborns in California. J Pediatr Haematol Oncol 2000;22(6):564-6.

3. Lachant NA. Haemoglobin $E$ : an emerging haemoglobinopathy in the United States. Am J Haematol 1987;25(4):449-62.

4. Premawardhena A, Fisher CA, Olivieri NF, et al. Haemoglobin E beta thalassaemia in Sri Lanka. Lancet 2005;366(9495):1467-70.

5. Bain BJ. Other significant haemoglobinopathies. In: Haemoglobinopathy diagnosis. Malden, MA: Blackwell Publishing 2006; 2 ${ }^{\text {nd }}$ ed:201-11.

6. Rees DC, Styles L, Vichinsky EP, et al. The haemoglobin E syndromes. Ann N Y Acad Sci 1998;850:334-43.

7. Sripichai 0 , Whitacre J, Munkongdee T, et al. Genetic analysis of candidate modifier polymorphisms in $\mathrm{Hb} \mathrm{E}$ beta 0-thalassemia patients. Ann N Y AcadSci 2005; 1054:433-8.

8. Premawardhena A, Fisher CA, Fathiu F, et al. Genetic determinants of jaundice and gallstones in haemoglobin E beta thalassaemia. Lancet 2001;357(9272):1945-6.

9. Singer ST, Kuypers FA, Styles L, et al. Pulmonary hypertension in thalassemia: association with platelet activation and hypercoagulable state. Am J Haematol 2006;81(9):670-5.

10. Atichartakarn V, Chuncharunee S, Chandanamattha P, et al. Correction of hypercoagulability and amelioration of pulmonary arterial hypertension by chronic blood transfusion in an asplenic haemoglobin E/betathalassemia patient. Blood 2004;103(7):2844-6. 